\title{
交通施設整備が住宅立地行動に与える影響に関する実証分析* \\ Empirical Analysis for Effect of Transportation Facility Improvement on Residential Location Behavior*
}

\author{
高木一成 $* *$ ・森本章倫***・古池弘隆**** \\ By Kazunari TAKAGI ** - Akinori MORIMOTO *** - Hirotaka KOIKE ****
}

\section{1.はじめに}

\section{（1）背景}

我が国は昭和 40 年代までは高度経済成長期であ り、都心部に急激に人口が集中する時代であった。 昭和 50 年代以後、人口動態は大きく恋わりはじめ た。都市への人口集中が沈静化するとともに、自動 車交通の増加などにより、市街地の低密度化が進行 し、都市基盤整備の不十分な市街地や各種の土地利 用が混在した市街地が形成された。一方で、既存市 街地での未利用地が増大し、十分な都市基盤整備が されないまま郊外に無秩序な開発が広がるスプロー ル現象が全国的な社会問題になっている。このよう な現象により、沿道地域での騒音問題や大気污染な どのように快適な都市環境が損なわれ、さらには交 通渋滞や事故多発といった都市問題の発生原因にま でなっている。これは交通・通信網の整備、モータ リゼーションの進展に伴った交通環境の変化が、住 宅をはじめとした立地行動を変化させたことが $1 つ$ の要因として挙げられる。しかし、実際に世帯の立 地行動の変化は交通環境の変化からだけではなく、 さまざまな要因によるものである。その立地行動の メカニズムは複雑であり、時代の経過とともに変化 するものである。

\section{(2) 既存研究との位置づけ}

これまで中村ら ${ }^{1)}$ をはじめとして、都市内の空 間構造を分析するための住宅立地モデルについての 方法論は発展し、数多くの研究がなされている。中 村らは、ある地点における世帯の期待効用と地価と の差である消費者余剩を立地余剩と定義し、この立

*キーワーズ : 交通施設整備, 住宅立地行動, 立地効用

**学生員 宇都宮大学大学院 工学研究科 建設学専攻 干321-8585 杤木県宇都宮市陽東 7-1-2

TEL/FAX : 028-689-6224

E-mail : mt033424@cc.utsunomiya-u.ac.jp

*** 正会員 工博 宇都宮大学工学部

****フェロー Ph.D 宇都宮大学工学部
地余剩の概念から CALUTAS モデルを構築した。 このモデルを用いて都市地域での土地利用変化を定 量的に予測している。宮本 ${ }^{2)}$ はランダム効用理論と ランダム付け值理論を同時に採用し、立地者側の不 確実性と土地所有者側の不確実性の両方をモデルに 反映させた RURBAN モデルを構築し、これを実際 の都市に適用している。林ら ${ }^{3)}$ は通勤交通改善を対 象として、交通改善効果の発生と帰着に関する理論 的整理を行い、効果計測に関する実際的なモデルを 構築している。この中で、交通改善効果を最終帰着 状態における土地所有者への資産価值上昇及び交通 施設利用者すなわち通勤世帯に残存する便益の両方 を整合的に捉えている。これらの研究では、非集計 モデルや立地競合および地価・地代のモデル化とい った方法を用いることにより立地行動を表現してい る。しかし、地価上昇期のものであることや交通手 段の差異に着目していないといった問題点もあり、 その方法論にはさらなる改善の余地を残している。

そこで本研究では、住宅費用と通勤費用の負担額 という視点から世帯の立地効用を分析し、住宅立地 行動を捉えていく。分析の際には交通手段別に通勤 費用を算出し、実データを用いて実際の立地行動と 比較していることに特色がある。

\section{2. 使用データと対象地域}

本研究はバブル期の地価高騰や、現在の地価下 落といった社会経済状況、交通施設整備に伴うアク セシビリティーの変化といった時代の変化に対応さ せるため、対象期を1985年、1990年、1994年、1999 年の 4 期とし、経年的に分析を行うこととする。本 研究で使用するデータのうち、人ロデータは宇都宮 市統計調查 ${ }^{4)}$ 、地価データとしては地価公示、交通 量データとしては道路交通センサス、住宅地費用の 推計には賃金労働時間制度等総合調査 ${ }^{5)}$ 、通勤費用 の推計には平成4年宇都宮都市圈パーソントリップ 調査等を用いる。また地理分析の際にはGISを用い る。対象地域は宇都宮市都市計画地域内の住宅地域 とする。 


\section{3. 住宅地地価モデル}

\section{（1）宇都宮市住宅地地価の推移}

宇都宮市の住宅地における平均地価の推移を図 1 に示す。宇都宮市においてはバブル経済による地 価高騰のピークは1991年であり、その後地価は下落 を続けている。つまり本研究の調查対象期のうち、 1985年、1990年は地価高騰期であり、1994年、1999 年は地価下落期である。

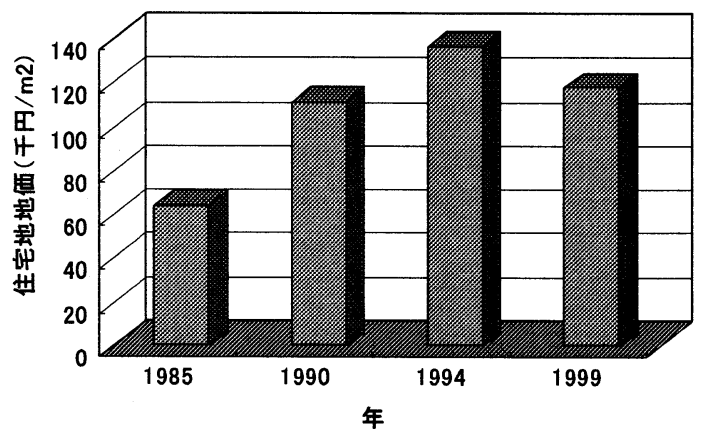

図1 宇都宮市住宅地地価の推移

\section{（2）住宅地地価モデルの作成}

これまで宇都宮市の地価に関する研究としては、 吉沢 ${ }^{6)}$ の宇都宮市の商業地域の地価形成要因に関 する研究がある。ここでは地価関数の6年間の変動 特性を明らかにし、道路整備効果の計測を行ってい る。この中で、地価形成要因としては都心からの距 離と都市ガスの整備、商業施設の集積度が大きく作 用していることがわかっている。本研究では、宇都 宮市の住宅地の地価関数の変動特性を把握するため に地価を目的変数にとり、重回帰分析を行う（11式 参照)。説明変数には、土地特性や都市計画規制、 アクセシビリティー、都市的インフラ、人口動態と
の関連を明らかにするために表 1 に示す変数をとる。 また変数の選定には、入手可能な変数のうち多重共 線性を避け、有用な独立変数を精選している。

$$
\begin{aligned}
& \ln Y_{i}=\sum a_{i} \ln X_{i}+b \quad \cdots(1) \\
& {\left[\begin{array}{l}
Y_{i}: i \text { 地点の推定地価、 } a_{i}: \text { 回㷌係数 } \\
X_{i}: \text { 価格形成要因、 } b: \text { 定数項 }
\end{array}\right]}
\end{aligned}
$$

各年ごとに分析を行い、表 1 に示す結果を得た。決 定係数はいずれも 0.8 以上であり、良好な結果が得 られている。標準回帰係数（以下回帰係数）の值を 比較すると、都心からの距離の回帰係数がいずれも 高いことがわかる。特に最寄り駅からの距離と比較 すると、その值は 5 倍以上高い值を示している。こ のことから、宇都宮市住宅地の地価は都市全体で見 た場合、最寄り駅からの距離よりむしろ、都心から の距離に大きく依存していることがわかる。また、 その值はマイナスであり、都心から離れると地価が 下がることがわかる。1985 年からそのマイナス值 は大きくなり、1990 年、1994 年にはピークを迎え たが、逆に 1999 年には值が若干低下している。こ れは、バブル期における都心部での急激な地価上昇 と、その後の地価下落による影響だと考えられる。

\section{4. 世帯の立地行動}

\section{（1）世帯の効用関数}

アロンゾ型都市モデルを用いて世帯の行動を考 える。アロンゾ型都市とは、円形でその中心に中 心業務地区(CBD)があり、世帯主はそこに勤務し、 また都市内の交通は CBD からすべての方向に放射 状に利用可能な都市である。世帯の効用関数 $u$ は (2)式のように表され、その関係を図 2 に示す。

\begin{tabular}{|c|c|c|c|c|c|c|c|c|c|}
\hline \multirow[b]{2}{*}{ 分類の指標 } & \multirow[b]{2}{*}{ 変数の説明 } & \multicolumn{2}{|c|}{ 1985年 } & \multicolumn{2}{|c|}{ 1990年 } & \multicolumn{2}{|c|}{ 1994年 } & \multicolumn{2}{|c|}{ 1999年 } \\
\hline & & 回㛿係数 & $\mathrm{T}$ 値 & 回㛿係数 & $\mathrm{T}$ 值 & 回㛿係数 & $\mathrm{T}$ 值 & 回熳係数 & $\mathrm{T}$ 值 \\
\hline 土地特性 & 地積 $(/ \mathrm{m} 2)$ & 0.046 & 0.98 & -0.134 & 0.77 & -0.040 & 0.82 & -0.012 & 0.37 \\
\hline 都市計画規制 & 容積率(\%) & -0.057 & 1.01 & -0.037 & 0.66 & 0.054 & 1.08 & 0.052 & 1.78 \\
\hline \multirow{3}{*}{$\begin{array}{l}\text { アクセシビリ } \\
\text { ティー }\end{array}$} & 最寄駅からの距離（km） & -0.056 & $2.06 *$ & -0.001 & 0.03 & -0.055 & $2.38 *$ & -0.029 & 1.83 \\
\hline & 都心からの距離 (km) & -0.248 & $6.62 *$ & -0.316 & $10.20 *$ & -0.315 & $10.52 *$ & -0.219 & $10.82 *$ \\
\hline & 12時間交通量(台) & -0.042 & 0.77 & 0.063 & 1.12 & 0.007 & 0.13 & -0.032 & 0.91 \\
\hline \multirow[b]{2}{*}{ 都市的インフラ } & ガスの有無 & 0.032 & 1.56 & 0.035 & 1.94 & 0.059 & $3.91 *$ & 0.050 & $5.19 *$ \\
\hline & 下水道の有無 & 0.028 & 1.48 & 0.028 & 1.55 & 0.010 & 0.44 & -0.013 & 0.66 \\
\hline \multirow{5}{*}{ 人口静態 } & 人口密度 (人/ $\left./ \mathrm{km}^{2}\right)$ & 0.054 & 1.49 & 0.060 & 1.80 & 0.020 & 0.59 & 0.024 & 1.07 \\
\hline & 事務所密度 (数 $\left./ \mathrm{km}^{2}\right)$ & 0.025 & 0.85 & 0.062 & $2.34 *$ & 0.036 & 1.81 & 0.030 & $2.16 *$ \\
\hline & 定数項 & 4.862 & $15.56 *$ & 4.919 & $9.42 *$ & 5.052 & $17.31 *$ & 5.071 & $25.55 *$ \\
\hline & 決定係数 & \multicolumn{2}{|c|}{0.869} & \multicolumn{2}{|c|}{0.907} & \multicolumn{2}{|c|}{0.837} & \multicolumn{2}{|c|}{0.846} \\
\hline & サンプル数 & \multicolumn{2}{|c|}{49} & \multicolumn{2}{|c|}{48} & \multicolumn{2}{|c|}{75} & \multicolumn{2}{|c|}{84} \\
\hline
\end{tabular}

\section{表 1 地価関数の推定結果}




$$
u=u(z, q) \quad \cdots \cdot(2)
$$

$q:$ 土地の広さ

$z$ : 土地の広さ以外の財・サービスを一緒にし た合成財

世帯主は都心で働き、ある期間に、所得 $y$ を得る とすると、世帯が都心から $t$ だけ離れた所に立地す るときの予算制約式は(3)式のように表される。

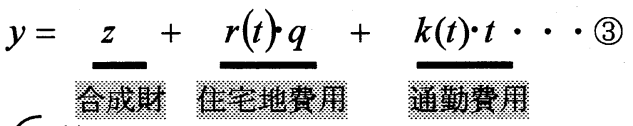

$$
\begin{aligned}
& {\left[\begin{array}{l}
r(t): \text { 地点 } t \text { での } 1 \mathrm{~m}^{2} \text { あたりの市場地代 } \\
k(t): 1 \mathrm{~km} \text { あたりの交通費 }
\end{array}\right.}
\end{aligned}
$$$$
\text { (2)、(3)式の条件の中で、世帯は効用を最大にする }
$$
ように立地行動を起こす。

\section{（2）立地効用最大化行動}

立地効用とは、世帯がある地点に立地すること によって得られる効用のことである。また、立地効 用最大化行動とは世帯が効用を最大にするような立 地行動のことである。ここで、交通施設が整備され たことにより、単位交通費用が $k(t)$ から $k^{\prime}(t) に$ 減少 したとする。すると合成財は $d z=\left\{k(t)-k^{\prime}(t)\right\} \cdot t+\{r(t)-$ $\left.r^{\prime}(t)\right\} \cdot q$ に增加し、それに伴い効用も $u$ から $u$ 'に増 加する (図 3 参照)。ただし、地点によって効用差 $u^{\prime}-u$ の増加分が異なるために世帯の立地行動が変化 する。つまり、世帯の立地効用最大化行動とは合成 財の増加分 $d z$ を最大にさせるための立地行動であ ると言い換えることができる。

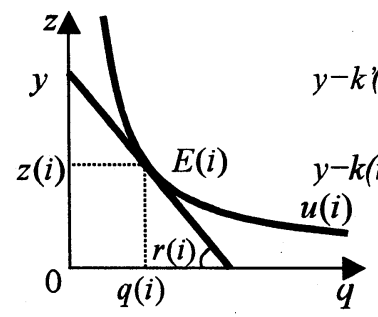

図2 世帯の効用関数

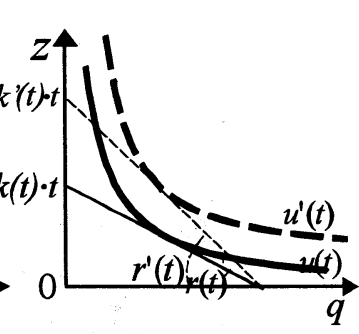

図3 効用関数の変化

\section{5. 交通施設整備による立地効用の変化}

\section{(1) 分析の視点と仮定}

4 章に基づき、都心からの距離別に住宅地費用 と通勤費用の負担額 $k^{\prime}(t) \cdot t+r^{\prime}(t) \cdot q$ を経年的に算出 し、合成財の変化分 $d z$ より立地効用の変化を分析 してゆく。本研究ではこのような視点から世帯の立 地効用を分析する。そこで、都市を単純化させるた めに以下のような仮定をおく。
I. 都市はアロンゾ型都市構造である。

II. 都心からの距離別の交通環境、地価などの土 地利用環境は一義的に定義され、距離帯別に 一定である。

III. 地代は地価に比例する。

IV. 立地に際し世帯が需要する土地面積は一定で ある。

V. 世帯の所得や嗜好性などといった属性は同一 である。

VI. 世帯主の 1 カ月あたりの通勤日数を 22 日とす る。

VII. 勤務先から一律の住宅手当が支給される。

VIII. 勤務先から通勤手当として公共交通の乗車代 金、乗用車の場合はガソリン代が支給される。

IX. バス・鉄道利用者には端末交通手段である徒 歩時間を考慮するため、通勤費用の中にバス は 6 分、鉄道は 10 分の時間単価を加える ${ }^{5)}$ 。

\section{（2）通勤費用と住宅地費用の算出}

本研究では、通勤費用と住宅地費用を以下のよう な方法によって算出する。

\section{a ）通勤費用 $k(t) \cdot t$}

人が移動のために費やす移動費用と、所要時間 を時間評価值により金額換算した時間費用とを合計 したものを通勤費用と定義する。ここで単位通勤費 用 $k(t)$ は、(4)式で表される。

$$
k(t)=\sum_{i} P_{i}^{t} \cdot m_{i}+\sum_{i} P_{i}^{t} \cdot c_{i} \quad \cdots(4)
$$

$$
\left(\begin{array}{ll}
P_{i}^{t} & : \text { 地点 } t \text { での交通手段 } i \text { の構成比 } \\
m_{i} & : \text { 交通手段 } i \text { の単位時間費用 } \\
c_{i} & : \text { 交通手段 } i \text { の単位移動費用 }
\end{array}\right.
$$

ここで交通手段構成比は、宇都宮都市圈 PT 調査 から通勤者の通勤距離別に交通手段を徒歩、自転車、 自動車、バス、鉄道の 5 つに分け算出した（図 4 参 照)。また、各交通手段のパラメータ值を表 2 の值 に設定する。本研究では、移動費用のほかに時間費 用を考慮するために時間価値を推計する。時間価値 の值を算出する際には、所得と労働時間により算出 される所得接近法と交通機関選択モデルにより算出 される選好接近法の 2 つ方法がある。特に、本研 究では通勤者を対象に行うため、所得接近法により 算出した宇都宮市の労㗢者の時間単価 51 円/分を用 いて時間費用を推計する。バスと鉄道の速度は宇都 宮市のそれぞれの平均速度》をとっている。また、 宇都宮市における自動車平均速度の変化 ${ }^{7)}$ に合わ せ、自動車の速度を表 3 のように設定する。バスと 
鉄道の移動費用に関しては、宇都宮市の実際の運賃 7) 8) 9) から単位移動費用を算出している。また、自 動車の移動費用は、ガソリン代だけでなく、初期投 資費用や維持費用などを考慮して設定した。以上を 用いて都心からの距離別の 1 力月あたりの通勤費用 を算出する。

\section{圆徒步圆自転車圆自動車圆バ鉄道}

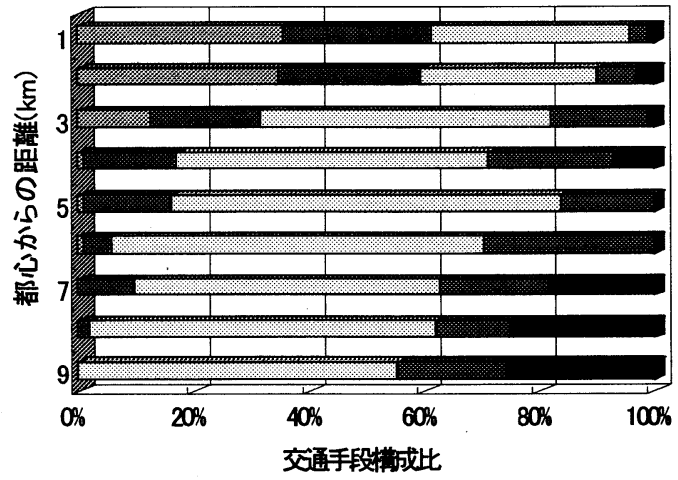

図4 通勤距離に対する交通手段棤成比 表2 交通手段別パラメータ

\begin{tabular}{|c|c|c|c|c|}
\hline . & (2.1.18. & (1) & 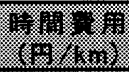 & 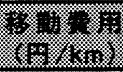 \\
\hline$\sqrt{13}$ & 4.8 & 12.5 & 650 & 0 \\
\hline 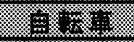 & 12 & 5 & 250 & 0 \\
\hline$\sqrt{12}$ & 20 & 3 & 150 & 40 \\
\hline 8 & 45 & 1.5 & 70 & 20 \\
\hline
\end{tabular}

表3 自動車パラメータの変化

\begin{tabular}{|c|c|c|c|c|}
\hline 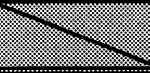 & 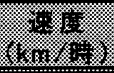 & 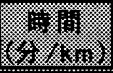 & $4=$ & 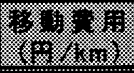 \\
\hline 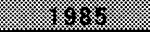 & 24 & 2.5 & 125 & 50 \\
\hline 090 & 28 & 2.2 & 110 & 50 \\
\hline ( 9984 & 31 & 1.9 & 95 & 50 \\
\hline 10.08 & 35 & 1.7 & 85 & 50 \\
\hline
\end{tabular}

\section{b ）住宅地費用 $r(t) \cdot q$}

住宅地費用は式(1)で求めた地価関数から推定で きるが、今回は過去の推移を検討するため、表 4 に 示す宇都宮市平均地代 $\left.{ }^{4}\right)$ を用いて各年各距離別に 算出する。算出の際、都心からの距離に対する人口 の 50\%タイル值に当たる地点の地代が平均值代で あると仮定し、距離帯に応じた地価関数をもとに地 代を按分している。また、住宅手当を一律に $16,210(\text { 円/月 })^{5)}$ とする。

表4 宇都宮市平均地代

\begin{tabular}{|c|c|c|c|c|}
\hline 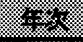 & 1088. & 1908 & 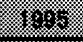 & 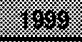 \\
\hline 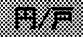 & 31,301 & 41,914 & 53,889 & 58,897 \\
\hline
\end{tabular}

（3）都心からの距離別の住宅・通勤負担額の推移 通勤費用 $k(t) \cdot t$ と住宅地費用 $r(t) \cdot q$ の 1 カ 負担額を都心からの距離別に算出し、通勤費用の負
担額を図 5 に、住宅地費用の負担額を図 6 に示す。 図 5 をみると、1985年から1999年にかけて都心部で は通勤費用の負担額はほとんど変化が見られないが、 郊外部で約1万円減少している。これは交通施設整 備が特に郊外部のアクセシビリティーを増加させた ものだと考えられる。図 6 をみると、住宅地費用は 全体的に増加傾向を示しているのがわかる。1985年 から1999年にかけて都心部では住宅費用の負担が約 4万円増加しているのに対し、郊外部では約2万円の 増加にとどまっている。これらの結果より、郊外部 における負担額の変化に比べ、都心部での負担額の 変化が著しく大きいことがわかる。これは、交通施 設の整備による都心への近接性の向上と、バブル期 における都心の急激な地価の上昇によるものだと考 えられる。

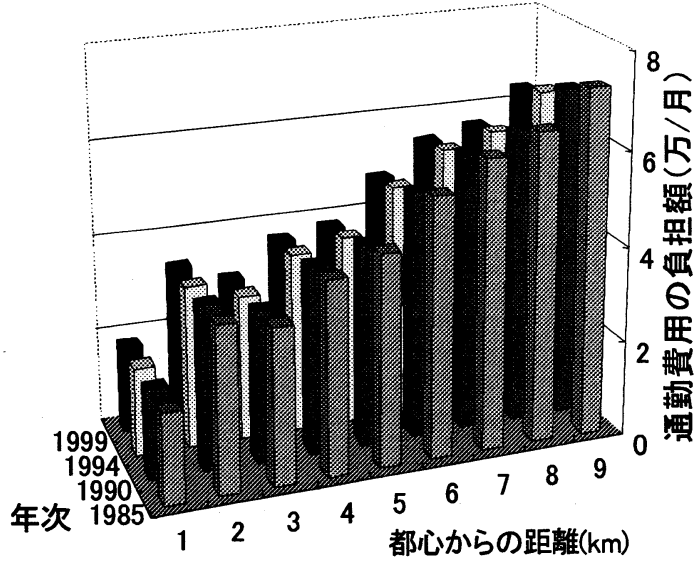

図5 都心からの距離に対する通勤費用の負担額

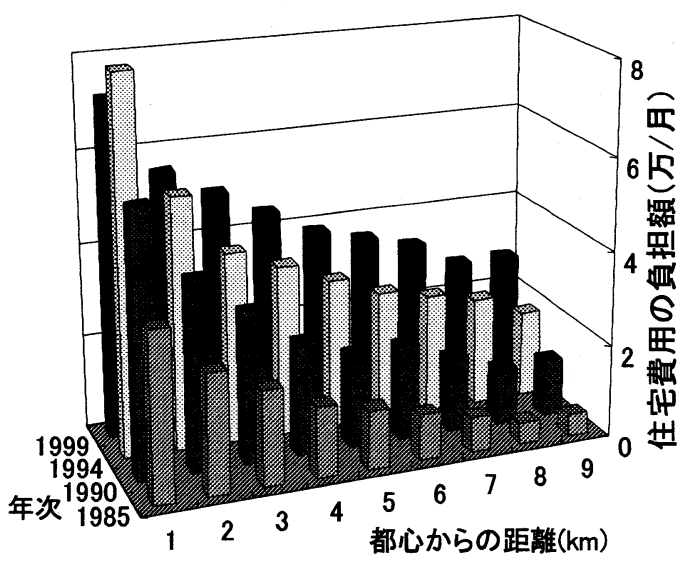

図6 都心からの距離に対する住宅費用の負担額

図 7 に都心からの距離別の通勤費用と住宅地費用 の1カ月あたりの負担額の合計を示す。これを見る と、住宅費用と通勤費用の負担額は都心部之郊外部 で高くなっており、おおよそ都心から $2 \mathrm{~km}$ 以降 $6 \mathrm{~km}$ までの範囲で低くなっていることがわかる。このよ 
うな負担額が低い地域では、世帯の立地効用が高い 地域であるといえる。以上より、1980年代までは都 心における負担は低く、つまり立地効用は高かった。 しかし、都心の立地効用はやがて時間の経過と共に 減少し、効用の高い範囲は都心から約 $2 \mathrm{~km}$ 以降 $6 \mathrm{~km}$ までの地域に移動したことが推測できる。

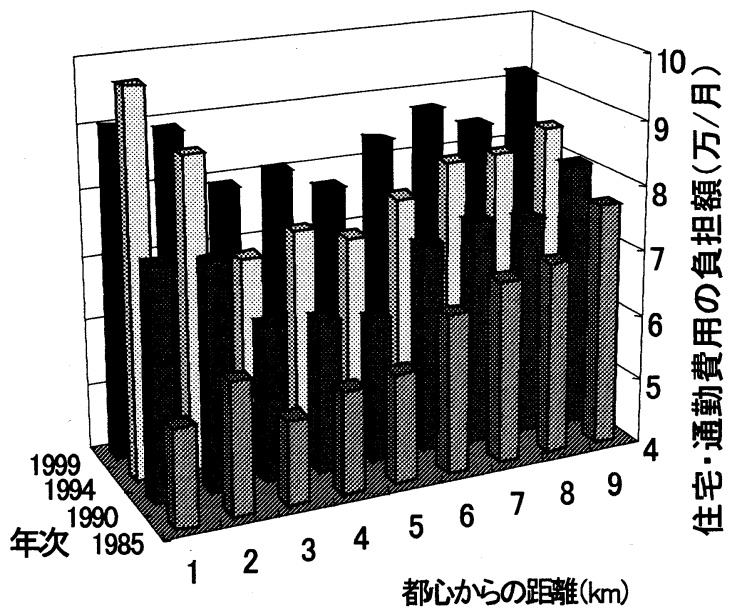

図7都心からの距離に対する住宅·通勤費用の負担額

\section{（4）立地効用の高い地域}

（3）より、宇都宮市の立地効用が高い地域であ る都心から $2 \mathrm{~km}$ からと $6 \mathrm{~km}$ までの範囲を対象地域上 に示す（図 8 )。宇都宮市は都心にJR宇都宮駅・東 武宇都宮駅があり、業務・商業地域が分布している。 また都心から郊外に向けて12の放射道路に加えて、 その周りを内環状線、さらに外環状線が通っている。 この図より、立地効用が高い地域は環状線などが通 った自動車にとって利便性のよい地域であることが わかる。

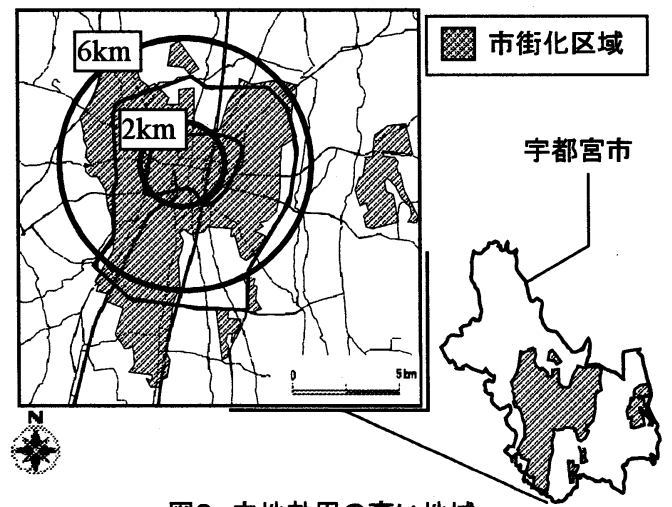

図8 立地効用の高い地域

\section{（5）通勤手当が支給されない場合}

ここで、通勤手当制度の影響を把握するために、 通勤手当が支給されない場合における都心からの距
離別の住宅・通勤費用の負担額を図 9 に示す。図 7 と比較すると、郊外部での負担が高くなっているこ とがわかる。これより、通勤手当制度は郊外部の立 地効用を高めている要因であると考えられ、都市の コンパクト化という面からも通勤手当制度は十分な 検討が必要であると考えられる。

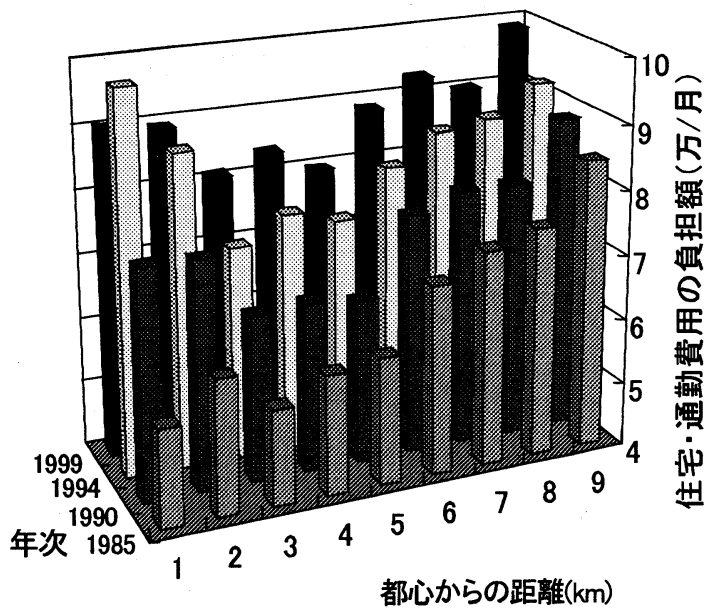

図9通勤手当がない場合の住宅·通勤費用の負担額

\section{6. 立地効用の変化による立地行動の変化}

1980年から1999年における、宇都宮市の都心から の距離に対する人口の推移を図 10 に示す。図 7 で 示された立地効用の高い地域で住宅立地、つまりは 人口が増加していることがわかる。逆に、立地効用 の低い地域では人口が減少している。このことより、 世帯の効用最大化行動によって立地効用が高い地域 では、他の地域に比べ、相対的に住宅立地が起こっ ていることが確認できる。つまり立地効用の差は人 口推移に大きな影響を与えていることがわかる。

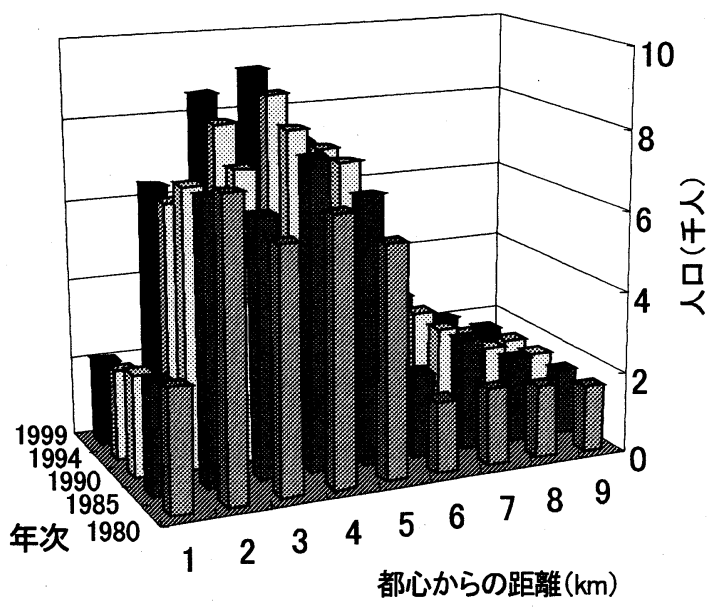

図10 都心からの距離に対する人口の推移 


\section{7. おわりに}

本研究では、通勤費用と住宅地費用の負担額とい う視点から立地効用を考えることにより、交通施設 の整備が与える世帯の立地行動の変化を経年的に把 握することができた。分析の結果、交通施設整備は 世帯に対して、交通環境の変化が通勤費用を変化さ せる直接効果とともに、周辺の地価を変動させて住 宅地費用を変化させる間接効果があり、これらによ って住宅立地行動が変化し、土地利用は変化してい くことが確認できた。

本研究では都市を単純化して分析を行っているた め、世帯の住み替え費用や所得の変化、所得階級の 違いといった世帯の嗜好性などを考慮していない。 このため、世帯の都市活動を十分に反映しきれてい ないといった課題も残る。そこで今後の課題として は、より詳細な地点ベースの解析、世帯の嗜好性を 考慮したモデル手法、立地効用值の推計手法と人口 移動への展開、商業・業務などの他の土地利用の立 地を考慮した分析などが挙げられる。
参考文献

1) 中村英夫 林良嗣 宮本和明 : 広域都市圈土地利 用交通分析システム、土木学会論文報告集、第 335号、pp141-153、1983

2) 宮本和明 : ランダム効用および付け值分析に基 づく土地利用モデルの札幌都市圈における適用、 土木工学研究・論文集、No.12、pp675-680、 1989

3）林良嗣 土井健司 : 交通改善に伴う通勤者の便益 の土地への帰着モデル、土木計画学研究・論文 集、No.6、pp45-52、1988

4) 宇都宮市 : 宇都宮市統計書、1980-2000

5) 労働省 : 賃金労働時間制度等総合調査、1999

6) 吉澤光三 宇於崎勝也 根上彰生 小嶋勝衛 : 地価 形成要因に関する実証的研究一宇都宮市の郊外 路線商業地域を対象として一、都市計画226、 pp42-48、2000

7) 建設省・栃木県、平成6年度宇都宮都市圈総合都 市交通体系調査報告書、1995

8）たとえば、東武鉄道 : http://www.tobu.co.jp/

9）たとえば、東日本旅客鉄道 : http://www.jreast.co.jp/ 10)佐々木公明 文世一：都市経済学の基礎、有斐閣 アルマ、2000

\section{交通施設整備が住宅立地行動に与える影響に関する実証分析*}

高木一成**・森本章倫***・古池弘隆****

交通施設整備の計画策定を行う場合、将来人口や土地利用の変化を把握することは、その効果分析や検 討、評価を行う上で重要な指標となる。しかし、立地行動のメカニズムは複雑であり、いまだわからない ことが多い。本研究では、都市における地価の変動や交通環境の変化といった現実のデータを反映させ、 交通施設整備の住宅立地行動に与える影響の実証分析を行う。また分析の際には、居住地決定を通勤費用 と住宅地費用の負担額という点からを捉え、住宅立地行動の変化を分析する。分析の結果、世帯は立地効 用最大化行動より、住宅地費用と通勤費用の負担額が低い地域に立地行動を起こす傾向があることがわか った。

Empirical Analysis for Effect of Transportation Facility Improvement on Residential Location Behavior *

By Kazunari TAKAGI ** • Akinori MORIMOTO *** • Hirotaka KOIKE ****

It is important to understand the change of population and land use by transportation facility. However, the mechanism of residential location behavior is so complex and variable. So, the purpose of this study is to examine the effect of transportation facility improvement on residential location behavior, by analyzing with actual data such as the records of land price and transportation condition in Utsunomiya City. And it is analyzed in terms of an contribution of commuting cost and housing cost. As a result, it can be confirmed that the residential location in the place where the location utility is high can attract more population than other places because of residential location maximizing behavior. 